\title{
Editorial
}

\section{Thinking outside the box: If not now, then when?}

\author{
International Journal of Disclosure and Governance (2009) 6, 1-3. doi:10.1057/jdg.2008.28
}

Over the last year or so, writing this editorial has proven a lot harder than I had bargained for. The problem is not the lack of material to cover, but the difficulty in keeping up with events. Little wonder that the old saying 'may you live in interesting times' is often described as the severest of curses.

Even that is an understatement of what has transpired during the last 3 months, when the entire capitalist system as we have known it has looked into an abyss last glimpsed a great depression and a world war ago. And it is far from clear whether we can climb out, when we will do so and what the world will look like when we do.

By way of comparison, consider that when Long Term Capital Finance collapsed in 1998, the intervention organised by the Federal Reserve cost $\$ 3.625$ billion, a figure which was a cause of scandal at the time. By contrast, the rescue package passed by a very reluctant US Congress in October 2008 was almost two hundred times larger, totaling $\$ 700$ billion, and even that was soon eclipsed by the multi-trillion dollar guarantees and capital injections into the banking sector implemented by European governments, led by Prime Minister Gordon Brown of the United Kingdom. ${ }^{1}$

Wholesale takeovers of banks, once considered the province of third world backwaters, has become not just a routine over the last few months, but positively demanded by the market. Indeed, US Treasury Secretary Paulson has been severely criticised by Wall Street for not moving as fast as the Europeans to 'directly inject capital' into banks, which is today's polite euphemism for what used to be called nationalisation.
Indeed, if there is one silver lining in the midst of all this disaster, it is the willingness to undertake actions thought unthinkable even a few months ago, and that, fortunately, means not just acts of desperation, but essential acts long considered out of reach. To turn to another old saying, 'every crisis is also an opportunity'.

I can hardly fail to mention the most historic of such outcomes, the election of Barack Obama to the presidency of the United States. Our readers no doubt have their own reaction to that extraordinary event, but just from the narrow perspective of governance and disclosure, what is important about his upcoming Democratic administration is that it increases the likelihood of a new era of market regulation akin to that of the 1930s which gave us annual financial statements and mandatory audit opinions.

We were already entering a time of unprecedented change with the mandating of XBRL and IFRS. ${ }^{2}$ Many foresee unprecedented regulation of hedge funds, derivatives, liability protection of audit firms, controls on enterprise risk management and perhaps the reopening of the SOX 404 issue and so on. Now is perhaps the time when the opportunity arises to actually implement many of the ideas that far sighted business people, including our own readers and authors have put forward over the years, and which were cavalierly dismissed in the boom times. And in that spirit, we inaugurate in this issue papers that put forward truly out of the box thinking for changing the way in which business has operated over the last few years - ways that have essentially followed unthinkingly despite many concerns about 
their inadequacy in the face of rapidly changing circumstances.

The first such example is the following Guest Editorial on bank boards by our esteemed founding editor, John Friedland, who also makes a welcome return to the journal with a detailed description of the background to the current credit crisis. But, as always, we seek all sides of an issue, and just to remind us why deregulation was so essential to the health and survival of capitalism, we also have a paper by Jim Bicksler examining the monumental work of Milton Friedman. In the 1980s Friedman's views transformed business, thanks to the courage of his greatest disciples, Margaret Thatcher and Ronald Reagan, in overturning decades of conventional wisdom about the superiority of state planning over free markets. What would Friedman have to say about the current swing towards re-regulation: a failure of his paradigm, or a necessary corrective to excessive 'animal spirits', to cite his great rival, John Maynard Keynes?

It will take many years before we know the full impact of the current crisis and its repercussions about how society views capitalism. But if there is to be an upside to the debacle, it will come from those with the far-sighted vision to look beyond the immediate alarms and quick fixes and to leverage the present to bring about a better future.

One final administrative note: along with the next IJDG journal conference due to be held in Beijing on March 13-14 of next year, I am also planning a special issue on XBRL for the middle of 2009, and an accompanying conference in Thessalonica, Greece on May 18-19. I hope our readers will participate in all these events, full details of which can be found on the journal website.

\section{NOTES}

1 While taking a break from writing the Editorial, I noticed a breaking news story that the US government will inject another $\$ 40$ billion into the ailing insurer AIG, in addition to the $\$ 123$ billion already invested. I doubt if this news will even warrant a mention in the popular media in the days to come, so used we have become to such government interventions on Wall Street.

2 Note the paper in this issue by Paul Pacter on the new version of IFRS for private entities.

Michael Alles

Editor

\section{Guest Editorial}

\section{Bank boards must govern}

International Journal of Disclosure and Governance (2009) 6, 2-3. doi:10.1057/jdg.2009.1

At the root of the current financial meltdown is lack of oversight - not only from without, by regulators, but just as importantly within the banks and former investment banks. Now that the government is infusing equity, it has both the leverage and a powerful financial incentive to insist that banks' boards of directors exercise much closer oversight. The kind of reform needed right now is corporate governance reform, particularly stricter oversight by bank boards of directors. Congress should act to create higher standards for the boards of the nation's largest banks as it implements the bailout.

Regulators failed to oversee derivatives, and banks' created wildly inadequate internal risk models. CEOs and CFOs chased bigger annual profits and personal bonuses at the expense of reason because their boards allowed them to. Directors stood by as their institutions assumed untold risk in exchange for immediate rewards.

Under current law, the CEO is often the chairman of the board, or and at a minimum is on the board. In the new dispensation, boards of directors should have the power to relieve CEOs of their seat on the board and require that 
they report like any other employee, allowing the board to deliberate without the CEO or the CFO present, as a rule.

Furthermore, instead of meeting four times a year, as they do now, boards should meet at least 10 times a year. Committees should meet far more frequently, and individual directors should $\log$ a minimum of 8 hours' work a week and double that for the nation's largest banks. Directors could make good use of this time. First, they could come to understand the risk that banks face over the longer term, and begin to manage it. It is ludicrous to suppose that directors can have an inkling of what is going on these behemoths in four meetings a year. Boards should have their own staff, and, either as individuals or as a group, access to all employees, lawyers, consultants, internal and external auditors, and accountants.

They would be a regular presence at their bank, setting a tone at the top and providing day-to-day supervision, rather than being merely visiting dignitaries to be handled by the CEO.

In recognition of their increased workload, $\$ 10$ million should be allocated for compensation for the boards of the nation's top five banks, or about $\$ 1$ million per year per board member. That would amount to a mere 0.000002 per cent of assets or 0.00002 per cent of capital, or less, for the top five banks by assets.

To further ensure objectivity, directors should not be granted options by the bank. Once it is established that they serve at the shareholders', not the senior corporate officers', pleasure, the practice should be for directors to serve long terms, outlasting CEOs.

A new class of directors must come into being. A search committee could take the lead. Some wrangling would occur as entrenched directors demonstrated reluctance to step down. Congress could help by passing legislation that would create personal liability for directors who are grossly negligent and lifetime bars for the ones found negligent.

Most importantly, legislation could mandate a minimum of 8 hours work per week for directors at banks with over $\$ 100$ billion in assets. This would serve as best practice, and smaller bank boards would increase their workloads.

Boards thus constituted and compensated could serve as a counterweight to corporate greed and consider the long-term interests of the bank or other financial institution, uninfluenced by incentive compensation issues.

There are, of course, two other solutions, either ending incentive compensation altogether, or treating banks like utilities, as proposed by Justice Louis Brandeis at the beginning of the century. Brandeis believed banks to be a natural money monopoly. But eliminating the profit motive from banking could have negative consequences including even less attention to asset quality as the result of incompetence as opposed to greed.

Some might claim that a board constituted and operating as outlined above would be rule by committee and would crimp the style of bank CEOs. Most banks, however, would have done better the last 10 years investing in Treasuries than following their leader's strategy.

Twenty-first-century governance for the banking industry must be implemented. The puny boards of the present day helped get us into this mess. After toying with less radical fixes, the next administration and Congress will discover that reform of corporate governance at the banks is the only real way to fix the financial system.

John Friedland Founding Editor International Journal of Disclosure and Governance 